\title{
ЗМІСТОВНО-ПОНЯТІЙНА ХАРАКТЕРИСТИКА СУБ’ЄКТИВНИХ ПУБЛІЧНИХ ПРАВ ФІЗИЧНОЇ ОСОБИ
}

Стрельников А. В.

Cтатmя присвячена дослідженню поняття mа змісту суб'єктивних публічних прав фізичної особи. Визначено, що суб'єктивні публічні права відіграють значну роль у структурі адміністративно-правового статусу фізичних осіб, оскільки за допомогою їх реалізації забезпечується реальна незалежність приватних осіб від держави, з'являються умови для інтеграції їх у публічно-правові відносини.

Встановлено, що суб'єктивне публічне право являє собою гарантовану законом індивідуально-конкретну міру можливої (дозволеної) поведінки особи, яка реалізується в межах конкретних правовідносин, з метою здійснення особистих інтересів та забезпечена відповідними обов'язками інших суб'єктів та гарантіями держави.

3'ясовано, що залежно від характеру інтересу, що покладений в основу суб'єктивного права, можна говорити про наявність: суб'єктивних приватних прав (в основі особистий приватний інтерес) та суб'єктивних публічних прав (основу становить публічний інтерес, тобто загальне благо). Встановлено, що суб'єктивні публічні права фізичної особи за своїм змістом можуть: посилити соціальну роль держави; забезпечити дієвість основних принципів правової держави; забезпечити обмеження публічної влади. Обгрунтовано, що суб'єктивні публічні права визначають рівень незалежності особи і забезпечують публічні інтереси, а в окремих випадках - $і$ вчинення суб'єктами публічного управління відповідних дій і прийняття рішень.

здійснено класифікацію суб'єктивних публічних прав. Виокремлено за критерієм змістовно-розширювального поділу три категорії суб'єктивних публічних прав людини і громадянина: а) права, які держава визнає за особистістю, і вони, відповідно, не можуть бути об'єктом посягання з боку останньої; б) права особистості на позитивні послуги з боку держави: право на освіту, створення державою матеріальних і процесуальних механізмів захисту прав і свобод громадян; в) права особистості на участь в управлінні державними справами і суспільством.

Ключові слова: фізична особа, суб'єктивні права, суб'єктивні публічні права, публічний інтерес, публічне управління.

(с) Стрельников А. В., 2020
Strelnykov A. V. Substantive and conceptual characteristics of the subjective public rights of an individual

The article is devoted to the study of the concept and content of subjective public rights of an individual. It is determined that subjective public rights play a significant role in the structure of the administrative and legal status of individuals, as their implementation ensures the real independence of individuals from the state, there are conditions for their integration into public relations.

It is established that subjective public law is a legally guaranteed individual-specific measure of possible (permitted) behaviour of a person, which is realized within a specific legal relationship, in order to pursue personal interests and secured by the responsibilities of other entities and state guarantees.

It was found that depending on the nature of the interest underlying the subjective right, we can talk about the presence of: subjective private rights (based on personal private interest) and subjective public rights (based on the public interest, i.e. common good). It is established that the subjective public rights of an individual in their content contribute to: strengthening the social role of the state; to ensure the effectiveness of the basic principles of the rule of law; ensure restrictions on public authority. It is substantiated that subjective public rights determine the level of independence of a person and ensure public interests, and in some cases - the actions of public administration of the relevant actions and decisions.

The classification of sub-active public rights has been created. According to the criterion of content-expansion division, three categories of subjective public rights of a person and a citizen are singled out: a) rights that the state recognizes as individuals and they, accordingly, cannotbeinfringed by the latter; $b$ ) theright of theindividual to positive services from the state: the right to education, the creation by the state of material and procedural mechanisms for the protection of the rights and freedoms of citizens; c) the right of the individual to participate in the management of public affairs and society.

Key words: individual, subjective rights, subjective public rights, public interest, public administration.

Постановка проблеми та іï актуальність. Інтеграція України до світової спільноти, її стратегія вступу до Європейського Союзу з перспективою набуття повноцінного членства $€$ потужними 
стимулами поглиблення в державі демократичних перетворень, приведення вітчизняного законодавства до міжнародних норм і стандартів, удосконалення системи захисту конституційних прав громадян. Серед великої кількості нерозв'язаних проблем гарантування конституційних прав та свобод громадян - реалізація ними їхніх суб'єктивних публічних прав, зокрема можливості щодо участі в управлінні державними справами, задля впливу на покращання діяльності органів державної влади та місцевого самоврядування і отримання на свою користь позитивних публічних послуг.

Більше того, утвердження «людиноцентристської» моделі побудови суспільства зумовило визначення нових векторів розвитку держави, зокрема спрямованістю на забезпечення прав, свобод і законних інтересів невладних фізичних і юридичних осіб, обслуговування суспільства та задоволення публічних інтересів. Зазначене призвело до посилення ролі фізичних осіб серед суб'єктів адміністративного права.

Аналіз останніх досліджень і публікацій. Науково-методологічне підґрунтя для дослідження питань змісту суб'єктивних публічних прав фізичних осіб становлять праці таких учених-адміністративістів, як: В. Авер'янов, О. Андрійко, Л. Біла-Тіунова, Ю. Битяк, В. Васильєва, І. Голосніченко, В. Селіванов, С. Ківалов, С. Савченко, О. Вінник, Є. Курінний, В. Колпаков, Т. Коломоєць та ін. Значення їхніх наукових праць у цій сфері дослідження не викликає ніяких сумнівів, однак категорія суб'єктивних публічних прав ними охарактеризована доволі фрагментарно.

Метою статті $\epsilon$ дослідження поняття та змісту суб'єктивних публічних прав фізичних осіб.

Виклад основного матеріалу. Дослідження проблематики визначення та виокремлення суб'єктивних публічних прав здійснювалося ще з кінця XIX - початку XX ст. Тоді активно висловлювалася вимога визнання за публічними правами якості, що властиві суб'єктивним правам особи. Водночас впровадження цієї категорії у правову доктрину здійснювалося головним чином поза межами вітчизняної науки.

Щодо західноєвропейських учених-адміністративістів, то вони доволі тривалий час активно обговорювали зазначену проблематику, намагаючись більш чітко окреслити правову природу та загальний зміст суб'єктивних прав. Українська ж адміністративно-правова наука в радянський період оголосила це вчення, як і інші важливі публічно-правові концепції, конструкції та категорії, «застаріло буржуазним», винесла його тим самим за рамки дослідницької уваги. Притаманне радянській науці розуміння адміністративної діяльності суто крізь призму управління людьми не сприяло розумінню індивіда як центральної фігури юридичної системи, отже, суб'єктивні права як інструмент його висунення в центр цієї системи також не осмислювались і не аналізувались [1, с. 29].

Аналіз наукових доробків дає підстави зробити висновок про те, що у європейській правовій науці суб'єктивні публічні права як правова категорія натепер досліджуються нечасто та загалом розуміються як суб'єктивні права приватних осіб, що виникають, змінюються та припиняються у відносинах із суб'єктами публічної адміністрації, що захищаються в порядку адміністративного судочинства (виступаючи елементом практичної адміністративно-юстиційної діяльності). Як видається, необхідним $є$ з'ясування самого змісту та структури поняття «суб'єктивне публічне право».

У лексичному плані «суб'єктивне право» визначається як: 1) закріплена законом і забезпечена державним захистом можливість суб'єктів права діяти (утримуватися від дій) певним чином і вимагати певних дій (утримання від них) від інших зобов'язаних осіб; 2) міра дозволеної поведінки особи, що закріплена в юридичних нормах; 3) право, що обов'язково реалізується в правовідносинах [2]. У теорії адміністративного права під суб'єктивним правом розуміють індивідуально-конкретну, вольову, владну міру свободи поведінки суб'єкта права, що характеризується такими ознаками, як: можливість вимагати належної поведінки від інших осіб, наявність інтересу та волі.

Як видається, у загальному розумінні суб'єктивне право - це гарантована законом індивідуально-конкретна міра можливої (дозволеної) поведінки особи з метою здійснення особистих інтересів та забезпечена відповідними обов'язками інших суб'єктів та гарантіями держави. Суб'єктивне право означає виражені в правовій нормі і встановлені в ній: а) свободу поведінки індивіда в межах, закріплених правовою нормою; б) можливість користування певним соціальним благом; в) повноваження на здійснення конкретних дій і право вимоги відповідних дій від інших осіб; г) можливість звернутися за захистом права у суд. Суб'єктивні права завжди пов'язуються з можливістю задоволення інтересів громадян у різних сферах (економічній, матеріальній, духовній та ін.) [3, с. 63].

Варто акцентувати увагу на тому, що суб'єктивне право - це не тільки (і не стільки) право 
на дії (свої або інших осіб), а перш за все право на користування матеріальними і нематеріальними благами, задоволення соціальних потреб i інтересів людей, право на участь у політичному житті країни, на участь у державному управлінні, на доступ до суспільних цінностей і благ. Тобто 3 матеріальної точки зору суб'єктивне право завжди означає можливість користування певними соціальними благами, а не просто міру можливої поведінки, яка є лише юридичним засобом для цього [4, с. 70].

Залежно від характеру інтересу, що покладений в основу суб'єктивного права, можна говорити про наявність:

суб'єктивних приватних прав (в основі особистий приватний інтерес);

суб'єктивних публічних прав (основу становить публічний інтерес, тобто загальне благо).

Відмінною рисою суб'єктивного приватного права від суб'єктивного публічного $є$ можливість здійснювати активні дії фізичною особою у вигляді вимоги щодо конкретної поведінки (або від іншої приватної особи, або від суб'єктів публічної адміністрації, зокрема і підприємств, установ, організацій незалежно від їх форм власності, у разі якщо вони виконують публічні функціі). Ще однією відмінною рисою можна вважати те, що суб'єкти публічної адміністрації та інші уповноважені суб'єкти, вчиняючи дії або приймаючи юридично значимі рішення, для задоволення публічного інтересу фізичної особи виконують свої службові повноваження. Окрім цього, сприяння у реалізації суб'єктивних публічних прав фізичною особою встановлюється та гарантується державою, зокрема шляхом застосування державного примусу, у тому числі адміністративного, що не характерно для суб'єктивних приватних прав. Видається, що, визначаючи суб'єктивні приватні права у законодавстві, держава обмежує можливість свого втручання у приватно-правову сферу встановленням міри дозволеної поведінки фізичної особи. Саме тому держава повинна сприяти виникненню постійного інтересу до державних справ, поєднуючи особистий (приватний) та публічний інтерес.

Видається за необхідне акцентувати увагу на тому, що поділ суб'єктивного права залежно від інтересу, який рушійною силою реалізації права відповідним суб'єктом є неоднозначним. Так, на думку А.І. Єлистратова, інтерес не придатний для обґрунтування конструкції публічного суб'єктивного права: «публичные права моментом интереса определяться не могут». «Широкий публичный интерес - это благо неограниченного и неопределенного круга человеческих существ». «Характеризуя публичные права ограждаемым ими общественным интересом, пришлось бы относить их как к субъектам, к безгранным массам людей (общество, народ и т. д.)» [5, с. 70, с. 119].

Крім того, трапляється думка з приводу доцільності виокремлення суб'єктивного публічного права особи з огляду на теорію поділу права на приватне та публічне. У такому разі суб'єктивним публічним правом визнається заснована на нормах публічного (адміністративного) права можливість приватної особи вимагати від публічної адміністрації такої поведінки, яка б задовольняла інтереси останньої [6, с. 116-117].

Я.М. Магазінер визначав суб'єктивне право як відкриту для особистості можливість безперешкодно діяти, коли держава встановлює за собою обов'язок не протидіяти здійсненню громадянами свободи дій [3, с. 63]. Видається, що загальне благо у вигляді юридично кваліфікованих публічних інтересів суспільства потрібно розуміти як основоположну умову здійснення приватних інтересів окремих індивідів.

Як видається, суб'єктивні публічні права відіграють значну роль у структурі адміністративно-правового статусу фізичних осіб, оскільки за допомогою їх реалізації забезпечується реальна незалежність приватних осіб від держави, з'являються умови для інтеграції їх у публічно-правові відносини. При цьому треба наголосити, що, незважаючи на вагомість значення суб'єктивних публічних прав, вони досі залишаються малодослідженими у адміністративно-правовій науці.

В.О. Федосенко, характеризуючи суб'єктивні публічні права, виокремлює їх специфічні ознаки, зокрема, такі як:

вони адресуються не конкретній особі, а пов'язуються із певним публічно-правовим статусом, який залежить від обсягу виконання певних функцій (депутата, судді, державного службовця та ін.);

критерієм ефективності та легітимаційною основою суб'єктивного публічного статусного права $\epsilon$ ступінь реалізації публічного інтересу: використання статусних прав обмежене у часі, воно припиняється разом із втратою статусу, після чого особа може користуватися лише окремими, статусними правами (наприклад, пенсійними, якщо це прямо закріплено у законі) [7, с. 17].

Такий підхід до виокремлення ознак суб'єктивних публічних прав $\epsilon$ не зовсім обґрунтованим, оскільки до уваги береться лише критерій статусу суб'єкта права, що реалізує відповідні суб'єктивні 
публічні права. Таким чином, поза увагою залишається сама правова природа відповідних прав.

3 урахуванням вищезазначеного видається за можливе виокремити такі сутнісні ознаки суб'єктивних публічних прав фізичної особи:

сферою реалізації є публічне адміністрування;

встановлюються та регламентуються нормами публічного права (зокрема, адміністративного та конституційного);

виникають та реалізуються лише в межах конкретних правовідносин;

метою їх запровадження $\epsilon$ захист конституційних прав громадян, зокрема, їх можливості щодо участі в управлінні державними справами задля впливу на покращання діяльності органів державної влади та місцевого самоврядування і отримання на свою користь позитивних публічних послуг;

передбачають можливість вимагати належної поведінки від інших осіб.

Для повної характеристики змісту суб'єктивних публічних прав видається за необхідне звернутися до класифікації таких суб'єктивних прав. Більше того, класифікації як методу наукового пізнання належить важлива роль у пізнанні і практиці, оскільки вона дає змогу охопити вивченням предмети за єдиною основою, установити не тільки місце кожного з них, але і зв'язки одного з одним, розкриває їхню внутрішню закономірність. Виокремлення різних видів суб'єктивних публічних прав $є$ результатом подільності змісту діяльності з публічного адміністрування на відносно самостійні та однорідні напрями впливу. Отже, вагоме значення має відповідь на запитання щодо видів суб'єктивних публічних прав, критеріїв їх класифікації, засад розмежування, здатності до поділу, деталізації тощо.

На думку Р.С. Мельника, суб'єктивні публічні права приватних осіб мають бути розділені на такі групи:

суб'єктивні публічно-політичні права (свободи) (свобода зібрання, свобода думки, право на повагу до гідності, право на свободу та особисту недоторканність тощо);

- суб'єктивні публічні права на отримання адміністративних послуг;

- суб'єктивні публічні права щодо користування публічним майном;

- суб'єктивні публічні права, пов'язані з участю в управлінні державними та муніципальними справами;

суб'єктивне публічне право на звернення до адміністративного суду за захистом порушених публічною адміністрацією прав, свобод та законних інтересів [8, с. 123].

До системи суб'єктивних публічних прав фізичних осіб П.В. Діхтієвський відносить:

1) право на свободу слова, зібрань, об'єднання, віросповідання;

2) права, пов'язані з участю громадян в управлінні державними справами (активне та пасивне виборче право, право на здійснення громадського контролю, право на участь у відправленні правосуддя);

3) право на отримання адміністративних послуг;

4) право на користування публічним майном (вулиці, площі, парки тощо);

5) права, пов'язані із можливістю захисту своїх прав і свобод (право на звернення) [9, с. 148].

3 урахуванням вищезазначеного видається за можливе виокремити три категорії суб'єктивних публічних прав людини і громадянина за критерієм змістовно-розширювального поділу:

права, які держава визнає за особистістю, і вони, відповідно, не можуть бути об'єктом посягання з боку останньої: право на недоторканість особистості і житла; таємниці листування; свободи пересування; свободи думки, совісті і релігії; свободи слова, друку та ін. Крім того, обов'язком держави є захист цих прав від посягання з боку суб'єктів публічного адміністрування;

права особистості на позитивні послуги з боку держави: право на освіту, створення державою матеріальних і процесуальних механізмів захисту прав і свобод громадян;

права особистості на участь в управлінні державними справами і суспільством: право вибирати і бути вибраним до органів державної влади і органів місцевого самоврядування, брати участь у референдумі.

Відповідно до ст. 3 Конституції України права і свободи людини та їх гарантії визначають зміст і спрямованість діяльності держави. Утвердження i забезпечення прав і свобод людини $\epsilon$ головним обов'язком держави [10]. Названі правові норми $\epsilon$ конституційною основою регулювання публічних відносин між людиною та державою. Крім того, зміст конституційних прав і свобод громадян показує зв'язок і взаємозумовленість інтересів держави і особистості, а також особистих і суспільних інтересів у структурі інтересів особистості. Таким чином, суб'єктивні публічні права покликані: посилити соціальну роль держави, забезпечити дієвість основних принципів правової держави та забезпечити обмеження 


\section{адміністративної реформи}

публічної влади. Суб'єктивні публічні права визначають рівень незалежності особи і забезпечують публічні інтереси, а в окремих випадках - і вчинення суб'єктами публічного управління відповідних дій і прийняття рішень.

Висновки. 3'ясовано, що утвердження «людиноцентристської» моделі побудови суспільства зумовило визначення нових векторів розвитку держави, зокрема, спрямованістю на забезпечення прав, свобод і законних інтересів невладних фізичних і юридичних осіб, обслуговування суспільства та задоволення публічних інтересів.

Визначено, що суб'єктивне публічне право являє собою гарантовану законом індивідуально-конкретну міру можливої (дозволеної) поведінки особи, яка реалізується в межах конкретних правовідносин, з метою здійснення особистих інтересів та забезпечена відповідними обов'язками інших суб'єктів та гарантіями держави.

Виокремлено сутнісні ознаки суб'єктивних публічних прав фізичної особи: а) сферою реалізації $\epsilon$ публічне адміністрування; б) встановлюються та регламентуються нормами публічного права (зокрема, адміністративного та конституційного); в) виникають та реалізуються лише в межах конкретних правовідносин; г) метою їх запровадження $\epsilon$ захист конституційних прав громадян, зокрема, їх можливості щодо участі в управлінні державними справами задля впливу на покращання діяльності органів державної влади та місцевого самоврядування і отримання на свою користь позитивних публічних послуг; ґ) передбачають можливість вимагати належної поведінки від інших осіб.

\section{Література}

1. Винницкий А. Учение о субъективных публичных правах vs. «государственно-управленче- ского подхода» в науке. Право и политика. 2018. № 12. С. 27-40.

2. Юридична енциклопедія: в 6 т. / за заг. ред. Ю.С. Шемшученка. Київ : «Укр. енцикл.», 2002. Т. 4: Н-П. 720 с. URL: http://leksika.com.ua/legal/ (дата звернення: 01.12.2020 р.).

3. Старилов Ю.Н. Адміністративна юстиція. Теорія, історія, перспективи. Москва : Видавництво HOPMA, 2001. 344 c.

4. Мацелик Т.О. Суб'єктивне юридичне право як юридичний феномен. Юридичний вісник. № 3(20). 2011. С. 67-71.

5. Елистратов А.И. Основные начала административного права : учебник. Москва : Издание Г.А. Леман и С.И. Сахаров, 1917. 304 с.

6. Мельник Р.С. Загальне адміністративне право : навчальний посібник Київ : Ваіте, 2014. 376 с.

7. Федосенко В.А. Субъективные права у публичной сфере : дис. ... канд. юрид. наук. Москва, 2007. 28 c.

8. Мельник Р.С. Система адміністративного права України : монографія. Харків : Вид-во Харківського національного університету внутрішніх справ, 2010. 432 c.

9. Адміністративне право України. Повний курс : підручник. Херсон : ОЛДІ-ПЛЮС, 2020. 584 с.

10. Конституція України від 28.06.1996 р. Дата оновлення: 01.01.2020 p. URL: https:// zakon.rada.gov.ua / laws / show / 254\%D0\%BA / 96 \%D0\%B2\%D1\%80 (дата звернення: 01.12.2020р.).

Стрельников А. В., кандидат юридичних наук, доцент кафедри адміністративного

і фінансового права Національного університету «Одеська юридична академія» 